\title{
PENGARUH PEMBAYARAN ZAKAT TERHADAP KEBERKAHAN USAHA \\ (Studi Kasus Pedagang Kain Songket di Pasar Kito Ilir Barat Palembang) Nilawati, S.Ag., M.Hum
}

\begin{abstract}
Abstrak
The concept 'berkah' is very abstract and relatively unmeasurable. As a religion that is transcendent and immanent, Islam not only must ma'qul (sensible), but also must ma`mul (applicable). Because of the dimensions of ma'qul and ma`mul, the concept of 'Berkah' still has to be proved empirically. is there a 'keberkahan' from zakat mall issued by muzakki after they issued zakat mall really proved, both transcendent they feel peace and tranquility much more intensive than what they felt before, or immanently (economically), for example in the form of increased turnover compared to the previous year.

This research will be inspected the effect of awareness of paying zakat mal against the blessing of effort by focusing case study study on songket traders in Pasar Kito. Selection of songket traders in Pasar Kito, because the majority of traders are Muslims. The methodology used in this study is to use the primary data by spreading the questionnaire to the songket trader in Pasar Kito. Then the existing data is analyzed by Classic Assumption test, hypothesis test and Linear Regression test using SPSS.

The results of the Research that is zakat payments have an influence on business blessings. Variable Payment of merchant's zakat has significant effect to the Business Responsibility. This is indicated by t count of 3.383 while $t$ table is 1.676 , which means $\mathrm{t}$ hitung $>\mathrm{t}$ table $(3,384>1,676)$ with significance $0,000<0,05$. then, Ho is rejected and Ha accepted, which means the payment of zakat has a positive and significant effect on the blessing of Palembang business. And the contribution of free variable (Payment of zakat) to the product of Business Concern is $52,5 \%$, while the rest $47,5 \%$ is explained by other variable not included in this research.
\end{abstract}

Keyword: Pembayaran Zakat, Keberkahan Usaha,

\section{Pendahuluan}

Dalam Islam sesungguhnya tidak terjadi polarisasi antara yang sakral (ibadah dan sistem credo) di satu sisi, dengan yang profan (muamalah) di sisi lain. Keduanya berkaitkaitan, sehingga membentuk satu kesatuan yang sinergis dalam kerangka ber-Islam atau berserah diri secara aktif di jalan yang digariskan Allah. Manifestasi dari berkait kaitannya sistem ajaran Islam itu (ibadah dan muamalah), dapat dilihat dari konsep zakat. Di samping berdimensi ibadah, zakat sekaligus juga berdimensi muamalah malliyah ijtimaiyyah. Zakat merupakan perwujudan yang paling gamblang dari kesatuan yang sinergis dari ajaran Islam tentang ibadah dan mumalah, karena selain mempunyai dampak individual sekaligus juga mempunyai dampak sosial. ${ }^{1}$

Seiring dengan jelasnya makna ibadah dalam zakat, terdapat pula di dalamnya sasaran-sasaran kemanusiaan yang luhur misalnya akhlak yang mulia dan nilai-nilai rohani yang tinggi. Nilai-nilai tersebut dalam Islam direalisasikan dan ditetapkan di balik kewajiban zakat ini, sebagaimana hal itu diingatkan oleh berbagai ayat dalam al-Qur'an dan hadis, serta dikemukakan pula oleh banyak ulama. Oleh karena itu, pada saat kaum

${ }^{1}$ Samdin, "Motivasi Berzakat: Kajian Manfaat dan Peranan Kelembagaan", dalam, Pusat Pengkajian dan Pengembangan Ekonomi Islam (P3EI) UII, Simposium Nasional I Sistem Ekonomi Islam, (Yogyakarta: P3EI, 2002), hlm. 448. 
muslimin melaksanakan syariat zakat sebagaimana diperintahkan Allah dengan semestinya, maka sasaran-sasaran kemanusiaan dalam kehidupan pribadi-pribadi seorang muslim dan kehidupan masyarakat Islam pada umumnya secara nyata akan mengalami peningkatan dalam kesejahteraan lahir dan batin. ${ }^{2}$

Sasaran dan hikmah zakat ini, bukanlah semata-mata bersifat materi saja, atau bersifat ruhani saja, melainkan bersifat materi dan juga ruhani. Di samping dianggap penting sasaran zakat di bidang mental dan akhlak, dipandang penting pula sasarannya di bidang ekonomi dan harta. ${ }^{3}$ Selain itu, sasaran-sasaran tersebut bukanlah semata-mata bersifat individual dan sosial saja, akan tetapi di antaranya ada yang kembali kepada pribadi si pemberi zakat atau si penerimanya, selain ada juga yang kembali kepada masyarakat Islam untuk merealisasikan keimanannya, menyebarkan risalahnya, dan memudahkan segala kesulitannya. ${ }^{4}$

Sebagai salah satu rukun agama, zakat merupakan sesuatu hal yang asasi dalam Islam. Dari penyebutannya dalam al-Qur'an yang di senafaskan dengan shalat, menandakan bahwa zakat sama kedudukannya dengan shalat, beserta rukun-rukun Islam lainnya. Namun berdasarkan pengamatan empiris, kesadaran umat Islam untuk menunaikan kewajiban zakat, tidak sekuat kesadaran mereka dalam menunaikan shalat. Karena dalam dataran realitas, terlihat banyak sekali orang Islam yang rajin menunaikan shalat setiap waktu, tetapi enggan menunaikan zakat, atau menunaikan zakat hanya terbatas pada zakat fitrah yang dikeluarkan pada menjelang hari raya Idul Fitri saja.

Hal tersebut bisa jadi disebabkan oleh hambatan yang ada dalam diri manusia yakni sifat manusia yang selalu menekankan dan memerlukan motivasi (termasuk motivasi ekonomi) dalam melakukan segala sesuatu, bahkan dalam menunaikan zakat yang sebenarnya merupakan kewajibannya sebagai seorang Muslim. ${ }^{5}$ Kenyataan bahwa dengan membayar zakat secara lahiriah mengurangi harta mereka, menutupi kesadaran tentang adanya hikmah dan manfaat dari pembayaran zakat tersebut, yang bukan hanya dapat dirasakan berupa pahala di akhirat kelak, namun juga di dunia, sebagaimana yang dijanjikan oleh Allah: ${ }^{6}$ Salah satu janji Allah tersebut, dalam kaca mata tafsir ekonomi bisa berarti memungkinkan berkembangnya harta, atau kembalinya harta yang dizakatkan tersebut dengan berlipat ganda kepada orang yang membayar zakat (muzakki), apakah ia menyadarinya ataupun tidak. ${ }^{7}$ Dalam bahasa sehari-hari, hikmah zakat yang dirasakan oleh para muzakki tersebut sering disebut sebagai "berkah".

Berbicara soal pembayaran zakat mal dikaitkan dengan implikasinya dalam konsep berkah, yakni adanya rasa tenang, damai, dan bahagia dengan "menta 'abbudikan" harta yang dimiliki bisa dikatakan sebagai suatu teka-teki akademis. Karena tidak saja konsep berkah itu sangat abstrak dan secara relatif tidak dapat diukur, melainkan juga hal itu mesti dipertanggungjawabkan secara epistimologis. ${ }^{8}$ Akan tetapi sebagai agama yang

${ }^{2}$ Yusuf Qardawi, Hukum Zakat, terj. Salman Harun, dkk, (Jakarta: PT. Pustaka Litera AntarNusa, 2002), hlm. 846.

${ }^{3}$ Ibid., hlm. 846.

${ }_{5}^{4}$ Yusuf Qardawi, Hukum Zakat, terj. Salman Harun, dkk, hlm. 846.

5 Secara lebih lengkap mengenai hambatan yang menyebabkan kewajiban zakat belum meluas tertunaikan dalam masyarakat, di mana salah satu butirnya menyebutkan bahwa sifat manusia yang kikir menghambat kesadaran mereka dalam membayar zakat lihat Departemen Agama, Motivasi Zakat, (Jakarta: Dirjen Binmas Islam dan Urusan Haji, 1997), hlm. 7-12.. (2): 276 .

6 Antara lain Q.S Saba (34):39, Q.S. al-Baqarah (2): 268, Q.S. ar-Rum (30):39, dan Q.S. al-Baqarah

${ }^{7}$ Yusuf al-Qardawy, Hukum.., hlm. 866.

${ }^{8}$ Konsep religius etik, seperti berkah, hikmah dan rahmah merupakan realisme methaphisik. Baik berkah, hikmah, maupun rahmah merupakan konsep methaphisik, akan tetapi dapat dimati secara rasionalempirical. Seseorang yang mendapatkan berakah, hikmah dan rahmah akan merasakan sesuatu yang 


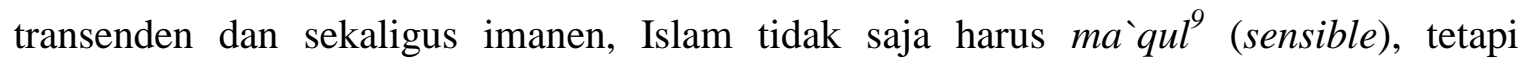
sekaligus juga mesti ma`mul (applicable). Berkait kelindannya dimensi ma`qul dan ma`mul tersebut, masih harus dibuktikan secara empirik, apakah adanya rasa "keberkahan" dari zakat mal yang dikeluarkan oleh muzakki setelah mereka mengeluarkan zakat mal benar-benar terbukti, baik secara transenden mereka merasakan kedamaian dan ketentraman jauh lebih intensif dari apa yang mereka rasakan sebelumnya, ataupun secara imanen (ekonomis), misalnya berupa peningkatan omzet usaha dibandingkan tahun sebelumnya.

Dalam kerangka tersebut penelitian ini akan melihat pengaruh kesadaran membayar zakat mal terhadap keberkahan usaha. Untuk lebih memfokuskan kajian, peneliti akan melakukan studi kasus terhadap padagang songket di Pasar Kito Ilir Barat. Dipilihnya pedagang songket di Pasar Kito tersebut, karena mayoritas pedagang beragama Islam.

\section{Metodologi Penelitian}

Penelitian ini merupakan penelitian lapangan (field research) dengan sifat penelitian deskriptif kuantitatif. Prosedur penelitian dilakukan dengan menggambarkan atau melukiskan keadaan, subjek atau objek penelitian yang diteliti yaitu penelitian yang mendasarkan pada perhitungan angka-angka atau statistik dari suatu variabel untuk dikaji secara terpisah-pisah kemudian dihubungkan dengan menggunakan rumus regresi. Data yang digunakan pada penelitian ini adalah data primer berupa quesioner yang dibagikan kepada pedagang songket yang ada di Pasar Kito Kota Palembang yang berjumlah 40 responden. Analisis data dilakukan dengan melalui prosedur uji Asumsi Klasik, uji regresi Linear sederhana, dan uji Hipotesis dengan menggunakan SPSS

Variabel pada penelitian kuantitatif berupa variabel bebas (independen) selanjutnya disebut varibel $\mathrm{X}$ adalah pembayaran zakat dan variabel terikat (dependen) selanjutnya disebut variabel Y, yaitu keberkahan usaha. Dengan definisi operasional sebagai berikut pada tabel dibawah ini

\begin{tabular}{|c|c|c|}
\hline Variabel Penelitian & Dimensi & Indikator \\
\hline \multirow[t]{2}{*}{ Pembayaran Zakat } & Kewajiban & $\begin{array}{l}\text { Merupakan kewajiban seorang muslim, } \\
\text { selain zakat fitrah dan amalan sunnah } \\
\text { lainnya, yang memiliki sistem } \\
\text { perhitungan tersendiri dengan } \\
\text { memperhatikan hisab dan haulnya }\end{array}$ \\
\hline & Hikmah & $\begin{array}{l}\text { Memiliki nilai hikmah dalam } \\
\text { membersihkan dan menambah harta serta } \\
\text { membersihkan harta, memiliki nilai } \\
\text { tanggung jawab sosial }\end{array}$ \\
\hline Keberkahan Usaha & $\begin{array}{l}\text { Manfaat } \\
\text { konkret }\end{array}$ & $\begin{array}{l}\text { Manfaat terhadap ibadah, harta dan } \\
\text { keluarga }\end{array}$ \\
\hline
\end{tabular}

menggembirakan, menyenangkan, membahagiakan dan merasa sukses di balik yang nampaknya memberi duka atau mengecewakan. Lihat: Noeng Muhadjir, Filsafat Ilmu Telaah Sistematis Fungsional Komparatif, (Yogyakarta: Rake Sarasin, 1998), hlm. 146

9 Ma $q u l$ artinya dapat dicerna penalaran (logis), sedangkan Ma`mul artinya dapat dicerna logika kesejarahan. Dengan demikian, yang pertama hadir dalam wujud maqal yang bersifat teoritis, sedangkan yang kedua hadir dalam wujud hal yang bersifat empirik. Masdar F. Mas'udi, "Zakat: Konsep Harta Yang Bersih", dalam, Budy Munawar-Rahman (ed)., Kontekstualisasi Doktrin Islam Dalam Sejarah, (Jakarta: Paramadina, 1995), hlm. 424 


\begin{tabular}{|l|l|l|}
\hline & $\begin{array}{l}\text { Manfaat } \\
\text { abstrak }\end{array}$ & Manfaat terhadap jiwa dan kehidupan \\
\hline
\end{tabular}

Sumber : diolah penulis

\section{Tinjauan Pustaka}

Posisi dan potensi zakat, menjadikannya senantiasa menarik dan aktual untuk diteliti. Banyak penelitian tentang zakat yang telah dilakukan baik dalam bentuk skripsi, tesis, maupun disertasi. Beberapa di antaranya akan ditelusuri pada bagian ini. Tesis tentang zakat ditulis oleh Saifuddin Zuhri ${ }^{10}$ meneliti sejauhmana konsep al-Qur`an tentang kesejahteraan melalui ZIS, serta apa ide dan pemikiran para ulama ataupun umara berkaitan dengan konsep al-Qur'an tentang kesejahteraan, serta sejauhmana realisasi pendayagunaan dana ZIS berkaitan dengan kesejahteraan masyarakat. Temuan yang dihasilkan penelitian Zuhri ini, antara lain adalah melalui zakat, infaq, dan sadaqah, pada dasarnya al-Qur`an mencanangkan kesejahteraan ekonomi, karena ketiga instrumen tersebut memmpunyai unsur kesamaan yakni sebagai ibadah maliyah, dimana hukum zakat adalah wajib, sedangkan infaq dan sadaqah adalah sunnah namun merupakan komplemen zakat. Sehingga apabila delapan asnaf yang merupakan sasaran zakat belum terpenuhi kesejahteraannya hanya dengan zakat, maka distribusi infaq dan sadaqah dapat diarahkan untuk memenuhi kekurangannya.

Sedangkan karya tulis yang bebrbentuk disertasi, antara lain ditulis oleh Abdurrachman Qadir. ${ }^{11}$ Disertasi ini menemukan sebenarnya terdapat hubungan fungsional antara kewajiban zakat dengan konsepsi keadilan, di mana zakat tersebut merupakan bentuk dari keadilan ekonomi yang merupakan hak dari delapan asnaf yang menjadi mustahiqnya. Oleh karena itu, menurut penulisnya lebih lanjut, seyogyanya dirumuskan kembali konsep teoretik dan operasional zakat yang berwawasan dan berorientasi pada nilai-nilai keadilan sosial, dalam upaya mengentaskan masyarakat dari kemiskinan.

Di luar tulisan-tulisan yang berupa hasil penelitian ilmiah di atas, penelitian tentang zakat pada umumnya menyoroti aspek manajemen pengelolaan. Di samping itu pustaka mengenai zakat, dilengkapi pula buku-buku yang terutama membahas mengenai aspek fiqh zakat, yang pada dasarnya buku-buku tersebut merupakan rujukan berbagai penelitian di atas, termasuk pula penelitian yang akan dilakukan oleh penulis sendiri. Buku-buku tersebut antara lain:, Fiqh as-Sunnah karya Sayyid as-Sabiq ${ }^{12}$, Al-fiqh al-Islam wa Adillatuh karya Wahbah az-Zuhayli ${ }^{13}$, karya Teungku Muhammad Hasbi ash-Shiddieqy yang berjudul Pedoman Zakat, ${ }^{14}$ buku yang ditulis oleh Yusuf al-Qardawi Fiqh az-Zakat, yang dalam edisi Indonesia diterbitkan dengan tajuk Hukum Zakat ${ }^{15}$, dan lain-lain.

Dari gambaran di atas dan sejauh penelusuran yang telah dilakukan penyusun, bisa dikatakan belum ada penelitian atau buku yang membahas mengenai implikasi pembayaran zakat terhadap berkah berusaha, terutama yang ditujukan terhadap para

10 Lihat Saifuddin Zuhri “Konsep Al-Qur`an Tentang Kesejahteraan Melalui Zakat, Infaq, Dan Sadaqah, Dan Implementasinya Pada BAZIS dan Koperasi Baitul Mu"awanah Di Desa Salam KanciBandongan, Magelang”. Tesis pada IAIN Sunan Kalijaga Yogyakarta, 1994, tidak diterbitkan.

11 Abdurrachman Qadir "Reaktualisasi Zakat: Telaah Teoretis Menurut Konsep Keadilan”., Disertasi pada IAIN Sunan Kalijaga Yogyakarta.

${ }^{12}$ Sayyid as-Sabiq, Fiqh as-Sunnah, (Beirut: Dar al-Fikr, 1983).

${ }^{13}$ Wahbah az-Zuhayli, Zakat Kajian Berbagai Mazhab, Alih bahasa oleh Agus effendi dan Bahruddin Fanany ( Bandung: Remaja Rosdakarya, 1995).

${ }^{14}$ Teungku Muhammad Hasbi ash-Shiddieqy, Pedoman Zakat, (Semarang: Pustaka Rizki Putra, 1999).

${ }^{15}$ Yusuf al-Qardawy, Hukum Zakat, terj. oleh salman Harun dkk., (Jakarta: Litera Antarnusa, 1987). 
pedagang songket di Palembang. Oleh karena itu, pada dasarnya penelitian ini layak untuk diteruskan.

\section{Kerangka Teoretik}

Dalam konteks penelitian ini, pada dasarnya variabel berkah dianggap sebagai motivasi dari variabel membayar zakat. Secara teoritis motivasi ada dua macam yaitu, motivasi intrinsik dan motivasi ekstrinsik. ${ }^{16}$ Motivasi intrinsik adalah kondisi yang mendorong dilakukannya suatu kegiatan atau tindakan yang berasal dari dalam perbuatan atau tindakan itu sendiri. Kondisi itu di dalam diri orang yang berbuat berbentuk kesadaran mengenai arti dan manfaat suatu perbuatan atau tindakan, baik bagi dirinya sendiri maupun orang lain dan masyarakat luas. Pendorongnya tidak lebih daripada kehendak atau keinginan agar perbuatan atau tindakan itu dilakukan oleh orang.

Dalam perspektif Islam motivasi dapat berbentuk pengabdian, yakni motivasi berbuat amal dan kebaikan, atau secara umum dapat dikatakan sebagai motivasi untuk mencari ridha Allah SWT. Motivasi intrinsik itu bagi orang-orang yang beriman termasuk para pemimpin, terpadu dengan keperibadian, kebutuhan dan tujuan perbuatan. ${ }^{17}$

Adapun motivasi ekstrinsik menurut Nawawi adalah kondisi yang mendorong dilakukannya suatu kegiatan atau tindakan, yang berasal dari luar perbuatan atau tindakan tersebut. Kondisi ini berbentuk sesuatu yang mengharuskan seseorang berbuat atau bertindak, agar kebutuhannya dapat dipenuhi. Sesuatu yang mendorong itu biasanya cenderung sesuai dengan salah satu atau semua unsur di dalam keperibadiannya. Sesuatu dari luar diri yang dapat mendorong seseorang untuk berbuat. ${ }^{18}$ Motivasi tersebut akan mempunyai nilai positif bilamana digunakan untuk mendorong sesorang berbuat amal kebaikan.

Dalam hal motivasi berzakat, Sedangkan faktor-faktor kelembagaan, dukungan pemerintah serta ulama, merupakan faktor ekstrinsik yang bersumber dari luar diri seorang muzakki. Sedangkan faktor-faktor seperti kekayaan yang dimiliki seseorang dan tingkat pengetahuan terhadap wajib zakat dapat dikategorikan sebagai faktor intrinsik, karena seseorang yang telah memiliki harta yang cukup untuk dan tingkat kesadaran keagamaannya yang tinggi untuk berzakat akan termotivasi untuk mengeluarkan zakatnya.. $^{19}$

Kesadaran untuk berzakat sebagai motivasi pribadi, sangat mungkin terkait dengan keyakinan adanya keberkahan" dari harta yang dimiliki dengan mengeluarkan zakatnya. Secara etimologis, zakat"memang berasal dari kata dasar dalam bahasa Arab zaka yang berarti tumbuh (numuww) dan bertambah (ziyadah) Jika diucapkan zaka al-zar, artinya adalah tanaman itu tumbuh dan bertambah. Begitu pula jika diucapkan zakat alnafaqah, berarti nafkah tumbuh dan bertambah jika diberkati. ${ }^{20}$ Oleh karena itu zakat juga

\footnotetext{
${ }^{16}$ Hadari Nawawi, Kepemimpinan Menurut Islam, (Yogyakarta: Gadjah Mada University, 1993), hlm. 107

${ }^{17}$ Ibid hlm. 108.

${ }^{18}$ Ibid.,

19 Samdin, "Motivasi Berzakat: Kajian Manfaat dan Peranan Kelembagaan", dalam, Pusat Pengkajian dan Pengembangan Ekonomi Islam (P3EI) UII, Simposium Nasional I Sistem Ekonomi Islam, , hlm. 452.

${ }^{20}$ Kata ini, juga sering dipakai untuk makna suci (taharah). Adapun dalam pengertian Syar`i, Zakat berarti hak yang wajib (dikeluarkan) dari harta seseorang. Mazhab Maliki mendefinisikannya dengan "mengeluarkan sebagian yang khusus dari harta yang khusus pula, dan telah mencukupi prosentase kuantitas yang mewajibkan zakat (nisab), serta diberikan kepada orang-orang atau golongan-golongan yang berhak menerimanya (mustahiq al-zakah). Dengan catatan bahwa kepemilikian seseorang atas harta tersebut merupakan kepemilikan penuh (milk al-tam) dan telah cukup tempo (haul).

Mazhab Hanafi mendefinisikan zakat dengan "menjadikan sebagian harta yang khusus sebagai milik orang yang khusus pula, yang telah ditentukan oleh syari at karena Allah". Kata "menjadikan sebgaian harta sebgai milik (tamlik) dalam definisi di atas dimaksudkan sebagai penghindaran dari kata pembolehan (ibahah).
} 
diartikan dengan berkah, selain dikemukakan pula untuk makna taharah yang berarti suci atau bersih. $^{21}$

Sedangkan zakat menurut istilah ahli fiqh adalah: "Sejumlah harta tertentu yang diwajibkan Allah diserahkan kepada orang-orang yang berhak", disamping" mengeluarkan jumlah tertentu itu sendiri". Jumlah harta yang dikeluarkan tersebut dinamakan 'zakat', karena dari yang dikeluarkan itu menambah banyak, membuat lebih berarti, dan melindungi kekayaan itu dari kebinasaan. ${ }^{22}$

Sebagai bentuk ibadah yang berdimensi sosial, zakat memiliki sasaran-sasaran kemanusiaan yang agung, yang bukan hanya dalam bidang mental dan akhlak melainkan sasaran di bidang ekonomi dan harta. Kedua sasaran tersebut antara lain tercermin bahwa dengan terdistribusikannya kekayaan ke tangan-orang-orang yang berhak dan membutuhkan melalui zakat, bisa menjaga ukhuwah (persaudaraan) antara umat Islam, karena dapat mengurangi kesenjangan yang ada antara orang kaya dan orang miskin. Lebih jauh lagi, manfaat dan hikmah zakat (baik secara materi maupun rohani) bukan hanya dirasakan oleh pihak yang menerima (mustahiq) saja, namun dapat dirasakan pula oleh pihak yang memberi (muzakki). ${ }^{23}$

Pengertian kata al-Mud'ífuun (orang yang melipat gandakan), jika dilihat dari kemungkinan tafsir di bidang ekonomi, bisa diartikan akan berlipat ganda hartanya karena zakat yang ia keluarkan tersebut, selain berlipat ganda pahalanya. Pengertian ini, pada dasarnya mendapat dukungan dari ayat-ayat lain dalam al-Qur'an, misalnya yang berarti: "dan barang apa saja yang kamu nafkahkan, maka Allah akan menggantinya, dan Dialah pemberi rizki yang sebaik-baiknya"(Q.S. Saba (34):39), "Syaitan menjanjikan (menakutnakuti) kamu dengan kemiskinan dan menyuruh kamu berbuat kejahatan (kikir), sedang Allah menjanjikan untukmu ampunan daripada-Nya dan karunia. Dan Allah Maha Luas (karunia-Nya) lagi Maha Mengetahiu".( Q.S al-Baqarah (2):268), dan "Allah memusnahkan riba dan menyuburkan sedekah"(Q.S. al-Baqarah (2): 276).

Dengan kerangka berpikir seperti inilah, penyusun ingin meneliti implikasi pembayaran zakat bagi pihak pemberi (muzakki) dalam hal ini parapedagang kain songket di Pasar Kito Ilir Barat Palembang, terhadap berkah dalam usaha mereka selanjutnya, terutama dengan melihat peningkatan kondisi sosial ekonomi keluarga mereka, peningkatan modal usaha, dan peningkatan omzet usaha mereka, dengan kata lain berkembangnya (berlipat gandanya) harta/ penghasilan para pedagang tersebut.

Menurut mazhab Syafìi, zakat adalah sebuah ungkapan untuk keluarnya harta atau tubuh sesuai dengan cara khusus. Sedangkan menurut mazhab Hanbali, zakat adalah hak yang wajib dikeluarkan dari harta yang khusus untuk kelompok yang khusus pula. Yang dimaksud dengan kelompok khusus di atas adalah delapan kelompok seperti diisaratkan Allah SWT. Dalam al-Qur'an:

"Sesungghuhnya zakat-zakat itu hanyalah untuk orang-orang fakir, orang-orang miskin, penguruspengurus zakat, para mu'allaf yang terbujuk hatinya kepada Islam, untuk (memerdekakan budak), orang0orang yang berutang, untuk di jalan Allah dan orang-orang yang sedang dalam perjalanan. Sebagai satu ketetapan yang diwajibkan Allah, dan Allah Maha Mengetahui lagi Maha Bijaksana. (QS. 9: 60) Lebih jauh lihat; Wahbah azZuhayli, Zakat Kajian Berbagai Mazhab, terj. oleh Agus effendi dan Bahruddin Fanany (Bandung: Remaja Rosdakarya, 1995), hlm. 82. bandingkan dengan Yusuf al-Qardawy, Hukum ..., hlm. 34.

${ }^{21}$ Lihat Q.S.asy-Syams (91): 9, Q.S. al- A'la (87):14, Q.S. at-Tur (53): 32, dan Q.S. at-Taubah (9):103. Dengan demikian bagi orang yang mengeluarkan zakat, hati dan jiwanya akan menjadi bersih, akan bersih pula kekayaannya. Dari pengertian zakat seperti ini mencerminkan bahwa zakat yang dikeluarkan oleh para muzakki akan dapat membersihkan dan mensucikan hati manusia, tidak lagi mempunyai sifat yang tercela terhadap harta: Lihat Budi Budiman," Potensi dana Zis Sebagai instrumen ekonomi Islam: Dari Teori dan Implementasi Manajemennya", dalam Proceedings..., hlm. 3.

${ }^{22}$ Yusuf al-Qardawy, Hukum..,hlm. 34.

${ }^{23}$ Q.S. ar-Rum (30): 39. 


\section{Hasil Penelitian}

Untuk mengetahui pengaruh pembayaran zakat pedagang songket terhadap keberkahan usaha dilakukan dengan perhitungan hasil kuesioner yang telah disebarkan kepada responden yaitu pedagang songket di pasar pusri sebanyak 40 orang.responden diminta untuk memberikan tanggapan atas pernyataan-pernyataan yang penulis berikan dari kuesioner tersebut.

Penulis tidak menyertakan nama dan instansi responden tetapi hanya karakteristik responden yang terdiri dari jenis kelamin, usia, dan penghasilan perbulan. Berikut ini disajikan tabel-tabel mengenai karakteristik responden :

\section{Karakteristik Responden}

Responden sebanyak 40 orang yang terdiri dari 23 orang dengan jenis kelamin perempuan dan 17 orang dengan jenis kelamin laki-laki.

Tabel IV.1

Distibusi responden berdasarkan jenis kelamin

\begin{tabular}{|c|c|c|}
\hline Jenis Kelamin & Jumlah & Persentase \\
\hline Perempuan & 23 & $57.5 \%$ \\
\hline Laki-laki & 17 & $42,5 \%$ \\
\hline Jumlah & 40 & $100 \%$ \\
\hline
\end{tabular}

Sumber: diolah tahun 2017

Berdasarkan tabel IV.1 responden dengan jenis kelamin laki-laki sebanyak 17 orang atau $(42,5 \%)$ dan perempuan sebanyak 23 orang atau $(57,5 \%)$.Dari tabel diatas berdasarkan jenis kelamin yang responden terbanyak adalah perempuan yaitu sebanyak 23 orang atau $(57,5 \%)$.

Tabel IV.2

Distibusi responden berdasarkan Usia

\begin{tabular}{|c|c|c|}
\hline Umur & Jumlah & Persentase (\%) \\
\hline$<25$ Tahun & 4 orang & $10 \%$ \\
\hline $26-35$ Tahun & 13 orang & $35,5 \%$ \\
\hline$\geq 36$ Tahun & 23 orang & $57,5 \%$ \\
\hline Jumlah & 40 orang & $100 \%$ \\
\hline
\end{tabular}

Sumber: data primer diolah tahun 2017

Berdasarkan tabel IV.2 menunjukan bahwa responden yang diambil sampelnya sebanyak 40 orang berdasarkan usia, terdiri dari 4 orang yang berusia dibawah 25 tahun atau $10 \%, 13$ orang atau 35,5\% berusia dari 26 - 35 tahun, dan 33 orang atau $57,5 \%$ lebih dari 36 tahun. Dari tabel diatas distribusi responden yang berdasarkan usia yang banyak adalah yang berusia $\geq 36$ tahun keatas.

Tabel IV.3

Distibusi Responden Berdasarkan Pendidikan

\begin{tabular}{|l|c|c|}
\hline \multicolumn{1}{|c|}{ Pendidikan } & Frekuensi & Persentase (\%) \\
\hline SMP & 7 & 17,5 \\
\hline SMA/SMK & 22 & 55 \\
\hline
\end{tabular}


Pengaruh Pembayaran Zakat Terhadap Keberkahan Usaha .... Nilawati

\begin{tabular}{|c|c|c|}
\hline Pesantren & 3 & 7,5 \\
\hline Sarjana/ Magister & 8 & 20 \\
\hline Total & $\mathbf{4 0}$ & $\mathbf{1 0 0}$ \\
\hline
\end{tabular}

Sumber: data primer diolah tahun 2017

Berdasarkan tabel IV.3 menunjukan bahwa responden yang diambil sampelnya sebanyak 40 orang berdasarkan pendidikan, terdiri dari 7 orang berpendidikan SMP atau 17,5\%, 22 orang yang berpendidikan SMA/SMK atau sebesar 55\%, 3 orang yang berpendidikan pesantren atau7,5\% dan 8 orang yang berpendidikan sarjana/magister atau 20\%.latar belakang responden dengan pendidikan SMA/SMK adalah yang mendominasi.

Tabel IV.4

Distibusi Responden Berdasarkan Penghasilan

\begin{tabular}{|l|c|c|}
\hline \multicolumn{1}{|c|}{ Pendidikan } & Frekuensi & Persentase (\%) \\
\hline < Rp. 1.000.000 & 3 & 7,5 \\
\hline Rp. $1.000 .000-$ Rp. 5.000.000 & 13 & 32,5 \\
\hline $\begin{array}{l}\text { > Rp. 5.000.000-Rp. } \\
\text { 10.000.000 }\end{array}$ & 16 & 40 \\
\hline > Rp. 10.000.000 & 8 & 20 \\
\hline \multicolumn{1}{|c|}{ Total } & $\mathbf{4 0}$ & $\mathbf{1 0 0}$ \\
\hline
\end{tabular}

Sumber: data primer diolah tahun 2017

Berdasarkan tabel IV.4 menunjukan bahwa responden yang diambil sampelnya sebanyak 40 orang berdasarkan penghasilan, terdiri dari 3 orang yang berpenghasilan $<\mathrm{Rp}$. 1.000.000 atau sebesar 7,5\%. Sedangkan yang berpenghasilan sebesar Rp. 1.000.000 - Rp. 5.000.000 adalah sebesar 32,5\% dari 40 responden, sebanyak 16 orang atau $40 \%$ berpenghasilan > Rp. 5.000.000 - Rp. 10.000.000. Dan sebanyak 8 orang atau $20 \%$ nya berpenghasilan diatas $>$ Rp. 10.000 .000

\section{Uji Validitas dan Reabilitas}

Untuk pengujian validitas dan reabilitas instrumen, penulis menggunakan bantuan program SPSS 16.0. Berikut hasil pengujiannya.

\section{a. Uji Validitas}

Untuk tingkat validitas dilakukan uji signifikansi dengan membandingkan nilai $\mathrm{r}_{\text {hitung }}$ dengan nilai $\mathrm{r}_{\text {tabel. }}$. Untuk Degree of freedom $(\mathrm{df})=\mathrm{n}-\mathrm{k}$. Dalam hal ini $\mathrm{n}$ adalah jumlah sampel dan k adalah jumlah konstruk. Pada kasus ini besarnya df, yaitu 40-2 atau $\mathrm{df}=38$ dengan alpha 0,05. Sehingga diperoleh $r_{\text {tabel }} 0.3120$ jika $r_{\text {hitung }}$ untuk masing-masing butir pertanyaan (dapat dilihat pada kolom corrected item total correlation) lebih besar dari $r_{\text {tabel }}$ dan nilai $r_{\text {hitung }}$ positif, maka butir pertanyaan dapat dinyatakan valid

Tabel IV.16

Hasil Uji Validitas Variable X

\begin{tabular}{|c|c|c|c|}
\hline Pernyataan & $\mathrm{r}$ hitung & $\mathrm{r}$ tabel & interpretasi \\
\hline 1 & 0,481 & 0.3120 & Valid \\
\hline 2 & 0,616 & 0.3120 & Valid \\
\hline 3 & 0,403 & 0.3120 & Valid \\
\hline
\end{tabular}


I-Economic Vol.4. No 1. Juni 2018

Pengaruh Pembayaran Zakat Terhadap Keberkahan Usaha .... Nilawati

\begin{tabular}{|c|c|c|c|}
\hline 4 & 0,300 & 0.3120 & Tidak Valid \\
\hline 5 & 0,270 & 0.3120 & Tidak Valid \\
\hline 6 & 0,693 & 0.3120 & Valid \\
\hline 7 & 0,576 & 0.3120 & Valid \\
\hline 8 & 0,438 & 0.3120 & Valid \\
\hline 9 & 0,356 & 0.3120 & Valid \\
\hline 10 & 0,692 & 0.3120 & Valid \\
\hline 11 & 0,698 & 0.3120 & Valid \\
\hline 12 & 0,607 & 0.3120 & Valid \\
\hline 13 & 0,671 & 0.3120 & Valid \\
\hline 14 & 0,444 & 0.3120 & \\
\hline
\end{tabular}

Sumber : Data primer yang diolah, 2017

Dari tabel IV.16 diatas, dapat diketahui bahwa masing-masing item pertanyaan pada setiap variabel $X$ memiliki nilai $r_{\text {hitung }}>r_{\text {tabel }}$ dan $r_{\text {hitung }}$. Dari hasil $r_{\text {tabel }}$ didapat hasilnya 0.3120 .Dengan demikian, semua item pertanyaan tersebut dinyatakan valid karena lebih besar dari 0.3120 kecuali item keempat dan kelima tidak valid, sehingga item ke empat dan kelima tidak kita gunakan lagi pada langlah selanjutnya.

Tabel IV.17

Hasil Uji Validitas Variable Y

\begin{tabular}{|c|c|c|c|}
\hline Pernyataan & r hitung & r tabel & interpretasi \\
\hline 16 & 0,669 & 0.3120 & Valid \\
\hline 17 & 0,644 & 0.3120 & Valid \\
\hline 18 & 0,728 & 0.3120 & Valid \\
\hline 19 & 0,725 & 0.3120 & Valid \\
\hline 20 & 0,773 & 0.3120 & Valid \\
\hline 21 & 0,571 & 0.3120 & Valid \\
\hline 22 & 0,597 & 0.3120 & Valid \\
\hline 23 & 0,653 & 0.3120 & Valid \\
\hline 24 & 0,771 & 0.3120 & Valid \\
\hline
\end{tabular}




\begin{tabular}{|c|c|c|c|}
\hline 25 & 0,745 & 0.3120 & Valid \\
\hline 26 & 0,655 & 0.3120 & Valid \\
\hline 27 & 0,432 & 0.3120 & Valid \\
\hline 28 & 0,450 & 0.3120 & Valid \\
\hline 29 & 0,749 & 0.3120 & Valid \\
\hline
\end{tabular}

Sumber : Data primer yang diolah, 2017

Dari tabel IV.17 diatas, dapat diketahui bahwa masing-masing item pertanyaan pada setiap variabel $Y$ memiliki nilai $r_{\text {hitung }}>r_{\text {tabel }}$ dan $r_{\text {hitung }}$. Dari hasil $r_{\text {tabel }}$ didapat hasilnya 0.3120 .Dengan demikian, semua item pertanyaan tersebut dinyatakan valid karena lebih besar dari 0.3120

\section{b. Uji Reliabilitas}

Untuk menguji reliabilitas instrumen dalam penelitian ini, kriteria yang digunakan yaitu dengan teknik cronbach alpha. Berdasarkan tabel Cronbach Alpa nilai minimal yang harus dicapai adalah 0,60 . Apabila diperoleh nilai cronbach alpha lebih besar dari 0,60, maka dapat dinyatakan reliabel.

Sumber:

Tabel IV.18

Tabel Uji Reliabilitas Instrumen

Data primer yang diolah, 2017

Dari tabel IV.18 diatas nilai cronbach alpha adalah 0.897. Ini berarti nilainya lebih besar dari 0,60. Dengan demikian, variabel pembayaran zakat (X) dan Keberkahan Usaha (Y) dapat dinyatakan reliabel karena punya korelasi yang cukup kuat. Jika dilihat dari per item dari pernyataan adalah sebagai berikut :

Tabel IV.19

Tabel Uji Reliabilitas Per item Item-Total Statistics

\begin{tabular}{|l|c|r|r|r|}
\hline & $\begin{array}{c}\text { Scale Mean } \\
\text { if Item } \\
\text { Deleted }\end{array}$ & $\begin{array}{c}\text { Scale } \\
\text { Variance if } \\
\text { Item Deleted }\end{array}$ & $\begin{array}{c}\text { Corrected } \\
\text { Item-Total } \\
\text { Correlation }\end{array}$ & $\begin{array}{c}\text { Cronbach's } \\
\text { Alpha if Item } \\
\text { Deleted }\end{array}$ \\
\hline VAR00001 & 89,45 & 204,203 &, 441 &, 894 \\
VAR00002 & 89,08 & 203,815 &, 492 &, 893
\end{tabular}


I-Economic Vol.4. No 1. Juni 2018

Pengaruh Pembayaran Zakat Terhadap Keberkahan Usaha .... Nilawati

\begin{tabular}{|l|l|l|r|r|} 
VAR00003 & 88,95 & 215,433 &, 127 &, 900 \\
VAR00006 & 88,68 & 196,276 &, 560 &, 891 \\
VAR00007 & 88,35 & 200,695 &, 522 &, 892 \\
VAR00008 & 88,15 & 212,387 &, 238 &, 898 \\
VAR00009 & 88,75 & 212,397 &, 255 &, 897 \\
VAR00010 & 88,38 & 198,548 &, 616 &, 890 \\
VAR00011 & 88,45 & 205,074 &, 398 &, 895 \\
VAR00012 & 88,70 & 208,318 &, 445 &, 894 \\
VAR00013 & 89,53 & 202,922 &, 503 &, 892 \\
VAR00014 & 88,90 & 209,733 &, 323 &, 896 \\
VAR00016 & 88,50 & 197,949 &, 603 &, 890 \\
VAR00017 & 89,03 & 203,102 &, 548 &, 891 \\
VAR00018 & 88,40 & 200,451 &, 521 &, 892 \\
VAR00019 & 88,43 & 197,584 &, 613 &, 890 \\
VAR00020 & 88,75 & 204,244 &, 605 &, 891 \\
VAR00021 & 88,65 & 208,079 &, 494 &, 893 \\
VAR00022 & 88,65 & 207,977 &, 498 &, 893 \\
VAR00023 & 88,75 & 206,808 &, 503 &, 893 \\
VAR00024 & 88,78 & 204,384 &, 621 &, 891 \\
VAR00025 & 89,38 & 199,574 &, 597 &, 890 \\
VAR00026 & 88,28 & 198,974 &, 567 &, 891 \\
VAR00027 & 88,55 & 211,844 &, 380 &, 895 \\
VAR00028 & 88,50 & 212,000 &, 895 \\
VAR00029 & 88,90 & 204,862 &, 516 &, 892 \\
\hline
\end{tabular}

Sumber : Data primer yang diolah, 2017

Dari tabel IV.19 diatas nilai cronbach's alpha if item deleted rata-rata menunjukkan nilai 0.897 . Ini berarti nilainya lebih besar dari $r$ tabel yaitu 0,3120 .. Dengan demikian, setiap item variabel pembayaran zakat (X) dan Keberkahan Usaha (Y) dapat dinyatakan reliabel

\section{Uji Asumsi Klasik}

a. Uji Normalitas

Uji normalitas bertujuan untuk menguji apakah dalam regresi, variabel terikat dan variabel bebas keduanya mempunyai distribusi normal atau tidak. Jika pada tabel test of normality dengan menggunakan One Sample Kolmogorov Smirnov nilai sig $>0,05$, maka data berdistribusi normal. Uji normalitas dalam penelitian ini adalah sebagai berikut:

Tabel IV.20

Uji Normalitas

One-Sample Kolmogorov-Smirnov Test

\begin{tabular}{|ll|r|r|}
\hline & & $\begin{array}{r}\text { Pembayaran_Zak } \\
\text { at }\end{array}$ & Keberkahan_Usaha \\
\hline $\mathrm{N}$ & Mean & 40 & 40 \\
Normal Parameters ${ }^{\mathrm{a}, \mathrm{b}}$ & Std. & 41,95 & 50,33 \\
& Deviation & 7,861 & 9,379 \\
Most Extreme & Absolute &, 090 &, 151 \\
Differences & Positive &, 080 &, 151 \\
Kolmogorov-Smirnov Z & Negative &,- 090 &,- 137 \\
&, 570 &, 956
\end{tabular}


Asymp. Sig. (2-tailed) , 902

a. Test distribution is Normal.

b. Calculated from data.

Sumber : Data Primer yang diolah, 2017

Pada tabel IV.20 dapat diketahui bahwa hasil uji One Sample Kolmogorov Smirnov menunjukkan variable Pembayaran Zakat nilai signifikan sebesar 0, 902 yang artinya lebih besar dari 0,05. Pada variable Keberkahan Usaha nilai signifikannya sebesar 0,320 yang artinya lebih besar dari $0,05$. . Dengan demikian, residual data berdistribusi normal dan model regresi telah memenuhi asumsi normalitas.

\section{b. Uji Linieritas}

Uji linieritas dimaksudkan untuk mengetahui apakah data yang akan dianalisis berhubungan secara linier atau tidak. Uji linieritas ini biasanya digunakan sebagai prasyarat dalam analisis korelasi atau regresi linear. Pengujian pada SPSS dengan menggunakan Test for Linearity dengan pada taraf signifikansi 0,05. Menurut Hadi, sebuah data dikatakan linier jika taraf signifikansi $<0,05$. Hal ini berarti variabel bebas bekorelasi linier dengan variabel terikat. Sebaliknya, jika nilai signifikansinya $\geq 0,05$, maka variabel bebas tidak berkorelasi linier dengan variabel terikat.

Tabel IV.21

Uji Linieritas

ANOVA Table

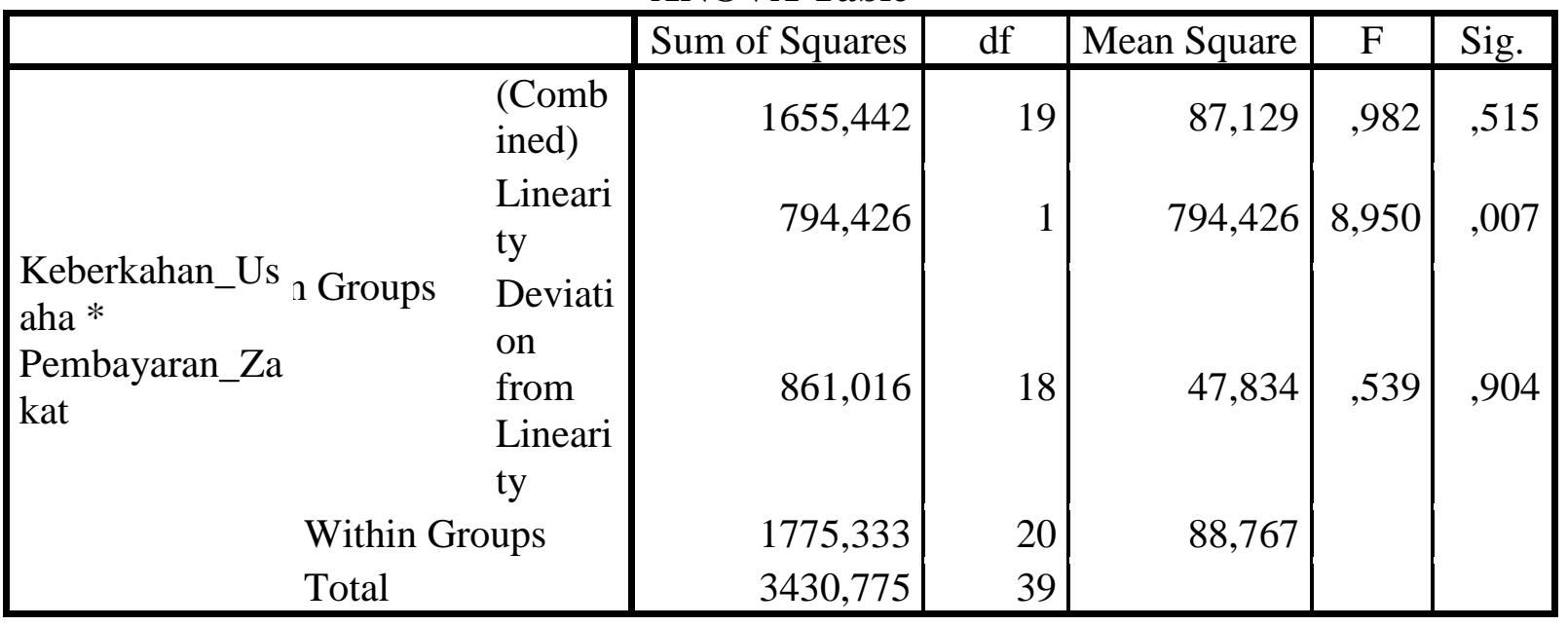

Sumber : Data Primer yang diolah, 2017

Berdasarkan tabel IV.21 diatas, dapat diperoleh nilai sig. Linearity sebesar $0,007<0,05$. Hal tersebut menunjukkan bahwa terdapat hubungan yang linier antara variabel Keberkahan Usaha dengan Pembayaran Zakat.

\section{c. Uji Heterokedastisitas}

Uji heteroskedastisitas bertujuan untuk menguji apakah dalam model regresi terjadi ketidaksamaan varian dari residual satu pengamatan ke pengamatan yang lain. Jika varian dari residual satu pengamatan lain tetap, maka disebut hemokedastisitas dan jika berbeda disebut heteroskedasitas.

Uji heteroskedastisitas bertujuan untuk menguji apakah dalam model regresi terjadi ketidaksamaan varian dari residual satu pengamatan ke pengamatan yang lain. 
Jika varian dari residual satu pengamatan lain tetap, maka disebut homokedastisitas dan jika berbeda disebut heteroskedasitas.untuk mendeteksi apakah ada atau tidaknyagejala heteroskedastisitas dapat dilakukan dengan melakukan uji White. Uji White menggunakan residual kuadrat sebagai variabel dependen, dan variabel independennya terdiri atas variabel independen yang sudah ada, ditambah dengan kuadrat variabel independen.

\section{Grafik IV.22}

\section{Uji Heterokedatisitas}

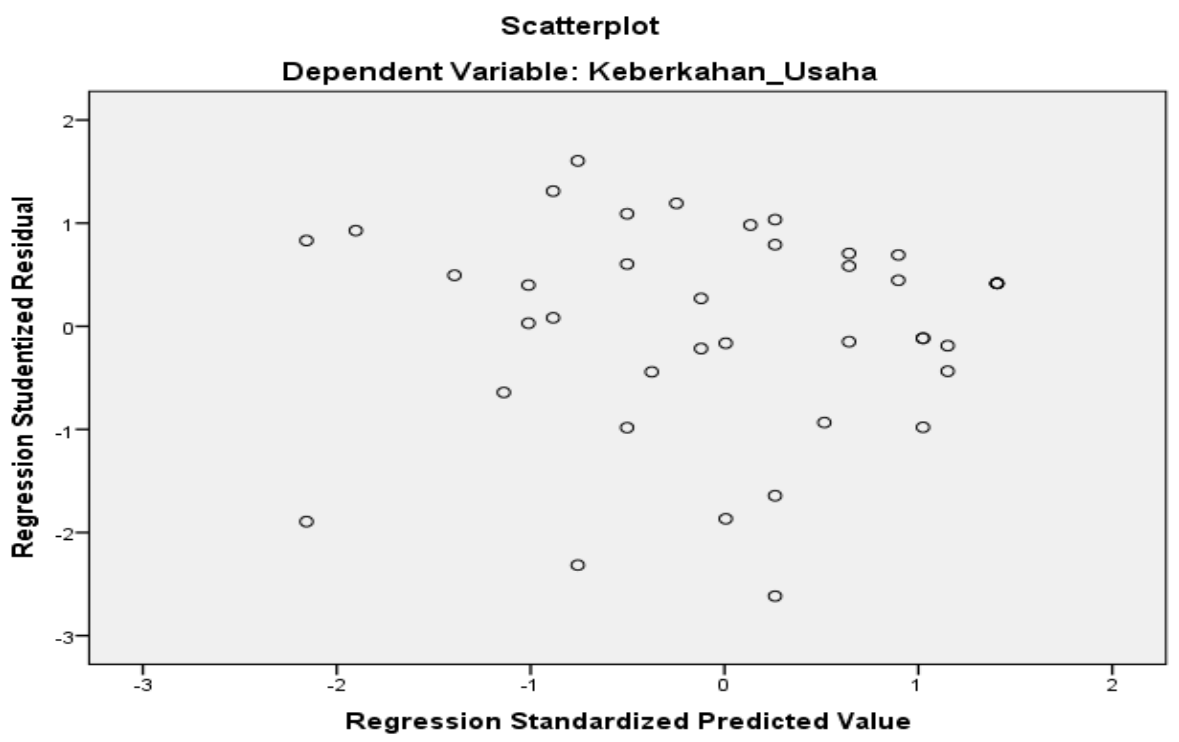

Pada grafik !V.22 tampak titik-titik menyebar di atas dan dibawah sumbu y, tidak terjadi pola tertentu, tidak mengumpul di satu ttitik, dan tidak membentuk gelombang yang melebar atau menyempit. Dengan demikian dapat disimpulkan bahwa tidak terjadi heterokedastisitas.

\section{Analisis Regresi Sederhana}

Dalam penelitian ini, analisis sederhana dilakukan untuk menganalisis hubungan antara pembayaran zakat (X) terhadap Keberkahan Usaha (Y). Analisi tersebut dilakukan dengan menggunakan program SPSS 16,0, sehingga diperoleh hasil sebagai berikut:

Tabel IV.24

\section{Analisis Regresi Sederhana}

\section{Coefficients $^{\text {a }}$}

\begin{tabular}{|l|r|r|r|r|r|}
\hline \multirow{2}{*}{ Model } & \multicolumn{2}{|c|}{$\begin{array}{c}\text { Unstandardized } \\
\text { Coefficients }\end{array}$} & $\begin{array}{c}\text { Standardize } \\
\mathrm{d} \\
\text { Coefficients }\end{array}$ & \multirow{2}{*}{ T } & \multirow{2}{*}{ Sig. } \\
\cline { 2 - 5 } & \multicolumn{1}{|c|}{ B } & Std. Error & Beta & \\
\hline \multirow{2}{*}{$\begin{array}{l}\text { (Constant) } \\
\text { Pembayaran_Za } \\
\text { kat }\end{array}$} & 26,239 & 7,239 & & 3,625 &, 001 \\
\hline
\end{tabular}

a. Dependent Variable: Keberkahan_Usaha 
Sumber : Data Primer yang diolah, 2017

Berdasarkan tabel IV.23 di atas, diketahui hasil analisis regresi yang diperoleh, yaitu koefisien untuk variabel Pembayaran zakat sebesar 0,574 dengan konstanta sebesar 26,239. sehingga, model persamaan regresi yang diperoleh adalah sebagai berikut:

$$
\mathrm{Y}=26,239+0,574 \mathrm{X}
$$

Dari Persamaan diatas didapati bahwasanya nilai $\mathrm{x}$ dan $\mathrm{y}$ adalah positif artinya variable $\mathrm{x}$ mempengaruhi secara linear variable $\mathrm{y}$, jika nilai $\mathrm{x}$ adalah sama dengan 0 maka nilai y adalah 26,239 dan setiap terjadi kenaikan nilai maka pengaruhnya adalah sebesar nilai konstan.

\section{Uji Hipotesis}

a. Uji t atau Parsial

Uji ini digunakan untuk melihat signifikansi variabel independen mempengaruhi variabel dependen yang dilakukan secara parsial atau individu. Uji signifikansi t ini ditunjukkan dengan thitung. Secara terperinci, hasil thitung dijelaskan dalam tabel berikut ini :

Tabel IV.24

Hasil Uji t atau Parsial

Coefficients $^{\mathbf{a}}$

\begin{tabular}{|c|c|c|c|c|c|}
\hline \multirow[t]{2}{*}{ Model } & \multicolumn{2}{|c|}{$\begin{array}{c}\text { Unstandardized } \\
\text { Coefficients }\end{array}$} & $\begin{array}{l}\text { Standardized } \\
\text { Coefficients }\end{array}$ & \multirow[t]{2}{*}{$\mathrm{T}$} & \multirow[t]{2}{*}{ Sig. } \\
\hline & B & Std. Error & Beta & & \\
\hline (Constant) & 26,239 & 7,239 & & 3,625 & $\overline{, 001}$ \\
\hline $\begin{array}{l}\text { Pembayaran_Zak } \\
\text { at }\end{array}$ & ,574 &, 170 & ,481 & 3,384 & ,002 \\
\hline
\end{tabular}

a. Dependent Variable: Keberkahan_Usaha

Sumber : Data primer yang diolah, 2017

Besarnya angka $t_{\text {tabel }}$ dengan ketentuan sig $=0,05$ dan dk $=(n-2)$ atau $(40-2)=$ 38 , sehingga diperoleh nilai $t_{\text {tabel }}$ sebesar 1,686. berdasarkan tabel IV.21 diatas, maka dapat diketahui dari tabel coefisients diperoleh nilai $t_{\text {hitung }}=3,384$ yang artinya $t_{\text {hitung }}>$ $\mathrm{t}_{\text {tabel }}(3,384>1,686)$ dengan signifikansi $0,000<0,05$. maka, Ho ditolak dan Ha diterima, yang artinya pembayaran zakat berpengaruh positif dan signifikan terhadap keberkahan usaha Palembang.

\section{b. Koefisien Determinasi (R2)}

Dari koefisien determinasi, dapat diketahui berapa besar kontribusi variabel independen (pembayaran zakat) terhadap variabel dependen (Keberkahan Usaha). Hasil perhitungan dengan program SPSS 16.0 adalah sebagai berikut :

Tabel IV.20

Koefisien Determinasi (R2)

Model Summary 


\begin{tabular}{|l|c|r|r|r|}
\hline Model & $\mathrm{R}$ & $\mathrm{R}$ Square & $\begin{array}{c}\text { Adjusted R } \\
\text { Square }\end{array}$ & $\begin{array}{c}\text { Std. Error of } \\
\text { the Estimate }\end{array}$ \\
\hline 1 & $.725^{\mathrm{a}}$ & .525 & .515 & 1.755 \\
\hline
\end{tabular}

a. Predictors: (Constant),

Pembayaran_zakat

b. Dependent Variable:

Keberkahan_Usaha

Sumber : data primer yang diolah, 2017

Hasil olah statistik pada tabel IV.20 yang dibantu dengan program SPSS 16.0 menunjukkan bahwa nilai $\mathrm{R}$ squarenya adalah 0,525 . Ini berarti variabel independen mampu menjelaskan variabel dependen sebesar 52,5\%, sedangkan sisanya 47,5\% dijelaskan oleh variabel lain yang tidak termasuk dalam penelitian ini. Hasil tersebut memberikan makna bahwa masih terdapat variabel independen lain yang mempengaruhi Keberkahan Usaha.

\section{Pembahasan Hasil Penelitian}

Pengaruh pembayaran zakat pedagang songket terhadap keberkahan usaha dilakukan dengan perhitungan hasil kuesioner yang telah disebarkan kepada responden yaitu pedagang songket di pasar pusri sebanyak 40 orang.responden. Dari hasil uji deskriptif, didapati bahwasanya responden dengan jenis kelamin laki-laki sebanyak 17 orang atau (42,5\%) dan perempuan sebanyak 23 orang atau (57,5\%).Dari tabel diatas berdasarkan jenis kelamin yang responden terbanyak adalah perempuan yaitu sebanyak 23 orang atau $(57,5 \%)$.

Berdasarkan usia, terdiri dari 4 orang yang berusia dibawah 25 tahun atau $10 \%$, 13 orang atau $35,5 \%$ berusia dari 26 - 35 tahun, dan 33 orang atau 57,5\% lebih dari 36 tahun. Dari tabel diatas distribusi responden yang berdasarkan usia yang banyak adalah yang berusia $\geq 36$ tahun keatas.

Berdasarkan pendidikan, terdiri dari 7 orang berpendidikan SMP atau 17,5\%, 22 orang yang berpendidikan SMA/SMK atau sebesar 55\%, 3 orang yang berpendidikan pesantren atau7,5\% dan 8 orang yang berpendidikan sarjana/magister atau $20 \%$.latar belakang responden dengan pendidikan SMA/SMK adalah yang mendominasi.

Berdasarkan penghasilan, terdiri dari 3 orang yang berpenghasilan $<\mathrm{Rp}$. 1.000.000 atau sebesar 7,5\%. Sedangkan yang berpenghasilan sebesar Rp. 1.000 .000 - Rp. 5.000.000 adalah sebesar 32,5\% dari 40 responden, sebanyak 16 orang atau $40 \%$ berpenghasilan > Rp. 5.000.000 - Rp. 10.000.000. Dan sebanyak 8 orang atau $20 \%$ nya berpenghasilan diatas $>$ Rp. 10.000.000.

Hasil dari uji validasi dan reabilitas menunjukkan bahwa uji validasi dikatakan valid apabila rhitung untuk masing-masing butir pernyataan (dapat dilihat pada kolom corrected item total correlation) lebih besar dari rtabel $>0,3120$ dan nilai rhitung positif, maka butir pernyataan tersebut dapat dinyatakan valid. Dilihat dari pengujian validasi bahwa masing-masing item pertanyaan pada setiap variabel memiliki nilai rhitung > rtabel dan rhitung bernilai positif. Dengan demikian, semua item pernyataan tersebut dinyatakan valid. setiap variabel memiliki nilai $r_{\text {hitung }}>r_{\text {tabel }}$ dan $r_{\text {hitung }}$. Dari hasil $r_{\text {tabel }}$ didapat hasilnya 0.3120.Dengan demikian, semua item pertanyaan tersebut dinyatakan valid karena lebih besar dari 0.3120 
Sedangkan hasil dari uji reabilitas menunjukkan pembayaran zakat terhadap kepercayaan nasabah semua nilai cronbach alpha sudah melebihi nilai $>60$ yang telah ditentukan. Nilai cronbach alpha dari uji realibilitas adalah 0.897. Ini berarti nilainya lebih besar dari 0,60. Dengan demikian, variabel pembayaran zakat (X) dan Keberkahan Usaha (Y) dapat dinyatakan reliabel.

Dari hasil uji asumsi klasik yang terdiri dari uji normalitas, uji Heterokedastisitas dan uji autokorelasi. Dari hasil uji Normalitas diketahui bahwa hasil uji One Sampe Kolmogorov Smirnov menunjukkan nilai signifikan sebesar 0,902 yang artinya lebih besar dari 0,902 (0,902 >0,05). Dengan demikian, residual data berdistribusi normal dan model regresi telah memenuhi asumsi normalitas. Dari hasil uji heterokedastisitas, grafik scatterplot menunjukkan bahawasanya titiktitik menyebar di atas dan dibawah sumbu y, tidak terjadi pola tertentu. Dengan demikian dapat disimpulkan bahwa tidak terjadi heterokedastisitas. Dari hasil uji Autokorelasi, dilihat dari nilai Durbin Watson menunjukkan nilai 1,755. Ini berarti tidak terdapat autokorelasi.

Pada uji hipotesis, diperoleh nilai $t_{\text {hitung }}=3,384$, sementara t tabelnya 1,676 , yang artinya $t_{\text {hitung }}>t_{\text {tabel }}(3,384>1,676)$ dengan signifikansi $0,000<0,05$. maka, Ho ditolak dan Ha diterima, yang artinya pembayaran zakat berpengaruh positif dan signifikan terhadap keberkahan usaha Palembang

Hasil dari uji R Square menunjukkan bahwa variabel independen mampu menjelaskan variabel dependen sebesar 52,5\%, sedangkan sisanya 47,5\% dijelaskan oleh variabel lain yang tidak termasuk dalam penelitian ini. Hasil tersebut memberikan makna bahwa masih terdapat variabel independen lain yang mempengaruhi kepercayaan nasabah.

Penelitian yang dilakukan sejalan dengan Ryan Adi Prasetya (2015) yang berjudul Dampak Zakat Terhadap Keberkahan Usaha Muzzaki. Secara kualitatif kajian ini menemukan bahwasanya pembayaran zakat memiliki pengaruh terhadap keberkahan usaha muzaaki..

\section{Simpulan}

Berdasarkan hasil pengolahan data Pengaruh Pembayaran zakat Pedagang Songket di Pasar Kito Terhadap Keberkahan Usaha dapat disimpulkan bahawasanya pembayaran zakat memiliki pengaruh terhadap keberkahan usaha. Variabel Pembayaran zakat pedagang berpengaruh signifikan terhadap produk Keberkahan Usaha. Hal ini ditunjukkan dengan thitung sebesar 3,383 sementara t tabelnya 1,676, yang artinya $t_{\text {hitung }}>t_{\text {tabel }}(3,384>1,676)$ dengan signifikansi $0,000<0,05$. maka, Ho ditolak dan Ha diterima, yang artinya pembayaran zakat berpengaruh positif dan signifikan terhadap keberkahan usaha Palembang. Serta kontribusi variabel bebas (Pembayaran zakat) terhadap produk Keberkahan Usaha sebesar 52,5\%, sedangkan sisanya $47,5 \%$ dijelaskan oleh variabel lain yang tidak termasuk dalam penelitian ini.

\section{Daftar Pustaka}

Agus Purwanto, Erwan dan Dyah Ratih Sulistyastuti. 2011. Metode Penelitian Kuantitatif untuk Administrasi Publik dan Masalah-Masalah Sosial. Yogyakarta: Gava Media

Amir, Taufiq. 2005.Dinamika Pemasaran: Jelajahi Dan Rasakan. Jakarta: PT Rajagrafindo Persada

Algifari. 2000. Analisis Regresi. Yogyakarta: BPEF UGM 
Alifudin dan Mashur Razak. 2015.Kewirausahaan Teori dan Aplikasi, Jakarta: MAGNA Script Publishing

Ali, Mohammad. 2014. Memahami Riset Perilaku dan Sosial. Jakarta: Bumi Aksara

Buchari, Alma dan Donni Juni Priansa. 2009. Manajemen Bisnis Syariah. Bandung: Alfabeta

Budisantoso, Totok dan Sigit Triandaru. 2011.Bank dan lembaga keuangan lainnya. Jakarta: Salemba Empat

Budisantoso, Totok dan Nuritomo. 2014.Bank dan lembaga keuangan lainnya.Jakarta: Salemba Empat

Dewan Syariah Nasional Majelis Ulama Indonesia. 2014. Fatwa Dewan Syariah Nasional MUI. Jakarta: Dewan Syariah Nasional Majelis Ulama Indonesia

Ghazaly, Abdul Rahman, dkk. 2010. Fiqh muamalat. Jakarta: PT Kharisma Putra Utama

Ghozali, Imam. 2006. Aplikasi Analisis Multivariate Dengan Program SPSS. Semarang: Badan Penerbit Universitas Diponegoro

Gunawan, Imam. 2015. Metode Penelitian Kualitatif Teori \& Praktik. Jakarta: Bumi Aksara

Habiburahim, Muhammad. 2012. Mengenal Pegadaian Syariah. Jakarta: Kuwais

Ismail. 2010. Manajemen perbankan dari teori menuju aplikasi.Jakarta: Predana Media Group

Ismail. 2011. Perbankan Syariah. Jakarta: Kencana

Kasmir. 2013. Bank dan lembaga keuangan lainnya. Jakarta: PT RajaGrafindo Persada

Mujahirin, Ahmad.2007. Ekonomi Islam, Jakarta: PT Raja Grafindo Persada

Sarwono, Jonathan. 2006. Metodelogi Penelitian Kuantitatif Dan Kualitatif. Jogjakarta: Graha Ilmi

Singgih, Santoso. 2000. Statistik Non Parametrik. Jakarta: PT Elex Media Komputindo

Sugiyono. 2014.Metode penelitian kuanitatif kualitatif dan $r \& d$.Bandung: Alfabeta Sugiyono. 2010.Metode Penelitian Pendidikan. Bandung: Alfabeta

Teguh, Muhammad. 2014.Metodologi Penelitian Ekonomi Teori dan Aplikasi.Jakarta: Rajawali Press, 2014 